FEDERAL RESERVE BANK of ST. LOUIS

\section{RESEARCH DIVISION} Working Paper Series

\title{
The Microstructure of the U.S. Treasury Market
}

\author{
Bruce Mizrach \\ and \\ Christopher J. Neely
}

Working Paper 2007-052B

https://doi.org/10.20955/wp.2007.052

April 2008

FEDERAL RESERVE BANK OF ST. LOUIS

Research Division

P.O. Box 442

St. Louis, MO 63166

The views expressed are those of the individual authors and do not necessarily reflect official positions of the Federal Reserve Bank of St. Louis, the Federal Reserve System, or the Board of Governors.

Federal Reserve Bank of St. Louis Working Papers are preliminary materials circulated to stimulate discussion and critical comment. References in publications to Federal Reserve Bank of St. Louis Working Papers (other than an acknowledgment that the writer has had access to unpublished material) should be cleared with the author or authors. 
Prepared for the Encyclopedia of Complexity, New York: Springer-Verlag

\title{
The Microstructure of the U.S. Treasury Market
}

\author{
Bruce Mizrach $^{*}$ \\ Department of Economics \\ Rutgers University \\ Christopher J. Neely \\ Research Department \\ Federal Reserve Bank of St. Louis
}

April 14, 2008

\begin{abstract}
This article discusses the microstructure of the U.S. Treasury securities market. Treasury securities are nominally riskless debt instruments issued by the U.S. government. Microstructural analysis is a field of economics/finance that examines the roles played by heterogenous agents, institutional detail, and asymmetric information in the trading process. The article describes types of Treasury issues; stages of the Treasury market; the major players, including the role of the Federal Reserve Bank of New York and the interdealer brokers; the structure of both the spot and futures markets; the findings of the seasonality/announcement and order book literature; and research on price discovery. We conclude by discussing possible future avenues of research.
\end{abstract}

JEL Codes: D53, E43, E44, G12,

Keywords: Treasury, microstructure, spreads, order book, announcement

* We would like to thank Dick Anderson, Frank Fabozzi, Michael Fleming, Robert Rasche and an anonymous referee for detailed comments which greatly improved this manuscript. The views expressed are those of the authors and do not necessarily reflect views of the Federal Reserve Bank of St. Louis or the Federal Reserve System. 


\section{Glossary}

Algorithmic trading Algorithmic trading is the practice of automatically transacting based on a quantitative model.

Broker A broker is a firm that matches buyers and sellers in financial transactions. An interdealer broker $(I D B)$ is an intermediary providing trading services to hedge funds, institutions, and other dealers. IDB's handle the majority of Treasury securities transactions in the secondary market.

Coupons Owners of Treasury notes and bonds receive periodic payments called coupons. They are fixed by the Treasury at auction and are typically paid semi-annually.

Depth Depth is the quantity the dealer is willing to sell at the bid or offer.

Electronic communications networks (ECN) The Securities and Exchange Commission defines electronic communications networks (ECNs) as "electronic trading systems that automatically match buy and sell orders at specified prices."

Market microstructure Market microstructure is a field of economics that studies the price formation process and trading procedures in security markets.

On-the-run On-the-run refers to the most recently auctioned Treasury security of a particular maturity. After the next auction, the security goes off-the-run.

Price discovery The process by which prices adapt to new information.

Primary dealers Primary dealers are large brokerage firms and investment banks that are permitted to trade directly with the Federal Reserve in exchange for making markets in Treasuries. They provide the majority of liquidity in the Treasury market, participate in Treasury auctions, and provide information to assist the Fed in implementing open market operations.

Secondary market After the initial auction of Treasury instruments, trading in on-the-run and off-the-run securities makes up the secondary Treasury market.

When issued When-issued bonds are those Treasuries whose auctions have been announced but have not yet settled.

\section{Definition of the Subject and Its Importance}

This article discusses the microstructure of the U.S. Treasury securities market.

U.S. Treasury securities are default risk free debt instruments issued by the U.S. government. These securities play an important, even unique, role in international financial markets because of their safety, liquidity, and low transactions costs. Treasury instruments are often the preferred safe haven during financial crises, a process often referred to as a "flight to quality." 
According to the U.S. Treasury, there was more than $\$ 9$ trillion in U.S. government debt outstanding as of August 31, 2007. Of this quantity, the public holds more than $\$ 5$ trillion and $\$ 4.5$ trillion is tradable on financial markets. Foreigners hold approximately $\$ 2.4$ trillion of the marketable supply, with Japan and China together holding more than $\$ 1$ trillion. According to the Securities Industry and Financial Markets Association (SIFMA), average daily trading volume in the U.S. Treasury market in 2007 was $\$ 524.7$ billion.

Microstructure is the study of the institutional details of markets and trading behavior. Microstructural analysis takes three ideas seriously that are often overlooked: the institutional features of the trading process influence how private information is impounded into prices; agents are heterogeneous; and information is asymmetric. Empirical microstructure research studies topics such as the causes and effects of market structure, how market structure influences price discovery, how trading and order flow reveal private information, how quickly public information is impounded into prices, the volatility-volume relation, and the determinants of transactions costs (i.e., the components of bid-ask spreads). The relatively recent availability of tick-by-tick financial data and limit order book data, as well as the computer resources to manipulate them, have been a great boon to financial market microstructure research.

\section{Introduction}

We begin by describing the types of Treasury issues and the major Treasury market participants, including the Federal Reserve, primary dealers and the major electronic brokers. We then outline the stages of the Treasury market, from auction announcements to the secondary market. Next, we examine several closely related areas of the literature: Seasonality in the Treasury market and the reactions of the Treasury market to macro and monetary announcements; discontinuities in Treasury prices; and the effect of order flow in Treasury markets. We then discuss modeling and other academic questions about the Treasury market.

\section{Types of Treasury Issues}

As of October 2007, the U.S. Treasury issued four types of debt instruments. The shortest-maturity instruments are known as Treasury bills. $22.6 \%$ of the marketable U.S. debt is in bills, securities with maturities of 1 year or less. Bills are sold at a discount and redeemed at their face value at 
maturity. They do not pay any coupons prior to maturity and currently have maturities up to 26 weeks. Treasury bill prices are usually quoted in "discount rate" terms, which are calculated with an actual/360 day count convention,

T-bill discount rate $=[$ face value - bill price $] \times(360 /$ number of days until maturity $)$.

Thus, a bill with a face value of $\$ 100,000$, a cash price of $\$ 97,500$ and 90 days to maturity will have a discount rate of $10 \%=[100-97.5] \times(360 / 90)$ in a newspaper. Treasury bill yields are often quoted as "bond equivalent yields," which are defined as,

$$
\text { T-bill yield }=\left[\frac{\text { face value }- \text { bill price }}{\text { bill price }}\right] \times(365 / \text { number of days until maturity }) \text {. }
$$

Treasury instruments with intermediate maturities (2-, 5- and 10-year) are known as Treasury notes. Notes pay semi-annual coupons, and make up 54.7\% of the debt. In February 2006, the U.S. Treasury also resumed issuing 30-year instruments, known as Treasury bonds. Bonds also pay semi-annual coupons, and make up $12.5 \%$ of the U.S. debt.

The price of both notes and bonds are quoted as a percentage of their face value in thirtyseconds of a point. A quoted price of 98-08 means that the quoted price of the note (or bond) is $(98+8 / 32=) \$ 98.25$ for each $\$ 100$ of face value. The cash price of bonds and notes is equal to the quoted price plus accrued interest since the last coupon payment, calculated with an actual/actual day count convention. Quoted prices are sometimes called "clean" prices, while cash prices are said to be "dirty."

The U.S. Treasury also issues 5-, 10-, and 20-year Treasury Inflation-Protected Securities ("TIPS"), whose payoff is linked to changes in the U.S. Consumer Price Index (CPI). These make up about $10.2 \%$ of the total value of Treasuries outstanding. The principal value of TIPS is adjusted daily and the semi-annual coupon payments and principal payment are then based on the adjusted principal amount. Economists extract inflation forecasts by comparing the TIPS yields to those on similar nominal instruments. The Federal Reserve Bank of Saint Louis provides "TIPS spreads" through its publication, Monetary Trends.

There is also an active market in STRIPS (Separate Trading of Registered Interest and Principal of Securities) which are popularly known as "zero coupon" bonds. These instruments are created by the Treasury through an accounting system which separates coupon interest payments and principal. Finally, the U.S. Treasury also issues savings bonds, low denomination securities for retail investors. 


\section{Treasury Market Participants}

\subsection{The Federal Reserve in the Treasury Market}

The Federal Reserve Bank of New York, under the guidance of the Federal Open Market Committee (FOMC), is a uniquely important player in the Treasury market. The FOMC meets approximately every six weeks to review economic conditions and determine a target for the federal funds rate, the rate at which U.S. banks borrow/lend reserve balances from/to each other. The manager of the Open Market Desk (a.k.a., "the Desk") at the Federal Reserve Bank of New York is responsible for ensuring that the average federal funds transaction is close to the target by buying and selling Treasury instruments (primarily short-term). In practice, the Desk accomplishes this in two ways. First the Desk buys sufficient Treasuries to satisfy most but not all the markets' demand for deposits at the Fed. Secondly, the Desk buys Treasuries via repurchase (repos) agreements (overnight and for terms of several days) to achieve a desired repo rate that influences the federal funds rate and other short-term interest rates through arbitrage.

To determine day-to-day actions, every morning, staff at both the Division of Monetary Affairs of the Board of Governors of the Federal Reserve System and the Desk forecast that day's demand for reserve balances. The Desk staff also consults market participants to get their views on financial conditions. The relevant Desk and Board staffs then exchange views in a 9 am conference call. Finally, the relevant Desk staff, the Board staff, and at least one of the voting Reserve Bank Presidents then confer during a second conference call at about 9:20 am. The Desk staff summarizes market conditions, projects actions for the day and asks the voting Reserve Bank President(s) for comments. Open market operations commence shortly after the conclusion of this call.

When the Desk buys Treasuries, it increases available liquidity (reserves) in debt markets and tends to lower interest rates. Selling Treasuries has the opposite effect, lowering reserves and raising interest rates. If the intention is to make a permanent change in reserves, then outright purchases or sales are undertaken. In contrast, if the Desk anticipates that only temporary changes in reserves are necessary, it uses repos (for purchases) or reverse repos (for sales). Bernanke [7] notes that actual open market sales of debt instruments are rare; it is more common for the Federal Reserve to allow such securities to expire without replacing them. Both open market sales and allowing the Fed's securities to expire have the same balance sheet effects: The Fed holds fewer bonds and more cash, while the public will hold more bonds and less cash. 
The Federal Reserve provides several valuable references on its operating procedures. The Annual Report of the Markets Group of the Federal Reserve Bank of New York describes open market operations and current procedures (Federal Reserve Bank of New York, Markets Group [26]). Meulendyke [57] provides a comprehensive view of Federal Reserve monetary policy operations with a historical perspective. Akhtar [1] explains how monetary policy is decided and how such policies affect the economy. Finally, Harvey and Huang [43] gives some historical perspective on operating procedures in the 1980s.

\section{$5.2 \quad$ Primary dealers}

Among the most important private sector players in the Treasury markets are the 21 primary dealers. The Federal Reserve Bank of New York explains that primary dealers must "participate meaningfully in both the Fed's open market operations and Treasury auctions and...provide the Fed's trading desk with market information and analysis that are helpful in the formulation and implementation of monetary policy." The Federal Reserve does not regulate primary dealers, but does subject them to capital requirements. The Federal Reserve can withdraw a firm's primary dealer designation if it fails to participate in auctions or open market operations or if its capital reserves fall below desired levels.

The daily average trading volume in U.S. Government securities of all the primary dealers was approximately $\$ 550$ billion during 2005 .

\subsection{Interdealer Brokers}

Prior to 2000, voice-assisted brokers dominated secondary market trading in Treasuries. Except for Cantor-Fitzgerald, all these brokers reported their trading activity to GovPX, a consortium. In the face of demands by the Securities and Exchange Commission and bond market dealers for greater transparency, five IDBs formed GovPX as a joint venture in 1991. In March 1999, CantorFitzgerald opened up its internal electronic trading platform, eSpeed, to clients. The eSpeed system quickly grabbed a dominant market share, and Cantor Fitzgerald spun off eSpeed as a public company in December 1999. In 2000, a competing electronic brokerage, BrokerTec, joined the market. As in foreign exchange and equity markets, most interdealer and institutional trading in Treasuries quickly migrated from voice networks to these electronic communications networks (ECNs), which have dominated trading in Treasury instruments since 2001. Mizrach and Neely [58] describe the transition from voice assisted trading, largely through the primary dealers, to 
electronic trading in the Treasury market.

As of November 2007, the two dominant ECNs are eSpeed and BrokerTec. London-based ICAP, PLC, owns BrokerTec while eSpeed merged in the summer of 2007 with BGC, another London based interdealer brokerage. eSpeed and ICAP compete for both on- and off-the-run liquidity. Hilliard Farber and Tullett-Prebon hold the largest brokerage share outside of the dominant two platforms.

\section{Stages of the Treasury Bond Market}

The sale of Treasuries undergoes four distinct phases: when issued, primary, on-the-run and offthe-run. Each of these stages has a distinct market structure.

\subsection{The Primary Market}

In the primary market, the U.S. Treasury sells debt to the public via auction. The U.S. Treasury usually publishes a calendar of upcoming tentative auction dates on the first Wednesday of February, May, August, and November and bids may be submitted up to 30 days in advance of the auction. In practice, however, the Treasury only announces firm auction information several days in advance and most bids are submitted at that time. Since August 8, 2002, the Treasury has made auction announcements (for all new securities) at 11:00 AM Eastern Time (ET). 13- and 26-week bills are auctioned weekly; 2- and 5-year notes are auctioned monthly; 10-year notes are auctioned eight times a year. 30-year bonds, which were reintroduced on February 9, 2006 after a five year hiatus, are auctioned four times a year.

The U.S. Treasury has used a single price auction exclusively since November 1998. Garbade and Ingber [35] discuss the transition from multiple price auctions to the current format single price auctions. All securities are allocated to bidders at the price that, in the aggregate, will result in the sale of the entire issue. This mitigates the risk of a "buyer's curse" - the highest bidder paying more than other auction participants. To prevent a single large buyer from manipulating the auction, the Treasury restricts anyone from buying more than $35 \%$ of any single issue. Bids may be submitted up to thirty days prior to the auction, and large institutions make use of the Treasury Automated Auction Processing System (TAAPS). Retail investors can participate through the Treasury Direct program. The Treasury allocates a portion of nearly every auction to small investors at the same price as the large institutions. These are called non-competitive bids, and they are quantity only 
orders that are filled at the market clearing price.

Primary dealers dominate the auction process. In 2003, they submitted $86 \%$ of auction bids, totalling more than $\$ 6$ trillion. They were awarded $\$ 2.4$ trillion, or $78 \%$ of the total auction supply.

\subsection{The Secondary Market}

The secondary market is composed of the when-issued, on-the-run and off-the-run issues.

When-Issued

Even prior to the primary auction, there is an active forward market in Treasury securities (apart from TIPS) that are about to be issued. Trading in the when-issued security market typically begins several days prior to an auction and continues until settlement of auction purchases. Nyborg and Sundaresan [61] document that when-issued trading provides important information about auction prices prior to the auction and also permits market participants to reduce the risk they take in bidding. Fabozzi and Fleming [25] estimate that $6 \%$ of total interdealer trading is in the when-issued market. Just prior to auctions though, these markets become substantially more active. In the bill market, when-issued trading volume exceeds the volume for the bills from the previous auction.

On-the-Run

Upon completion of the auction, the most recently issued bill, note or bond becomes onthe-run and the previous on-the-run issue goes off-the-run. Overall Treasury trading volume is concentrated in a small number of on-the-run issues. Trading in these benchmark on-the-run issues, which Fabozzi and Fleming [25] say constitutes approximately $70 \%$ of total trading volume, has migrated almost completely to the electronic networks. Mizrach and Neely [58] estimate a $61 \%$ market share for the BrokerTec platform and a 39\% share for eSpeed in 2005, which is consistent with industry estimates.

Off-the-Run

With more than 200 off-the-run issues trading in October 2007-44 bills, 116 notes, and 45 bonds - most off-the-run volume takes place in voice and electronic interdealer networks. Barclay, Hendershott and Kotz [5] document the fall in ECN market share when issues go off the run. They also report that transaction volume falls by more than $90 \%$, on average, once a bond goes 
off-the-run. The ECN market share falls from $75.2 \%$ to $9.9 \%$ for the 2 -year notes, from $83.5 \%$ to $8.5 \%$ for the 5 -year notes, and from $84.5 \%$ to $8.9 \%$ for the 10 -year notes. Several IDBs handle most off-the-run securities trading.

On- versus Off-the-Run Liquidity and Prices

Off-the-run securities trade at a higher yield (lower price) than on-the-run securities of similar maturity. Many researchers have attempted to explain the yield differential with relative liquidity. Vayanos and Weill [68] utilize a search theoretic model that is motivated by the fact that bonds may be difficult to locate once they go off-the-run. Goldreich, Hanke, and Nath [36] compare onthe-run and off-the-run Treasuries and show that the liquidity premium depends primarily on the amount of remaining future liquidity, which is highly predictable. The study exploits the fact that the liquidity of a Treasury is predictable. Duffie [18] argues that legal or institutional restrictions on supplying collateral induces "special" repo rates that are much less than market riskless interest rates. The price of the underlying instrument is increased by the present value of the savings in borrowing costs.

\section{Supply Variation and Prices}

Although it is generally accepted that the on-the-run premium is due to greater liquidity, the theoretical relation between the supply of a given bond issue and prices is not clear. Do issue sizes produce lower yields (higher prices) through their liquidity effects or whether downwardsloping demand for individual securities would produce higher prices (lower yields) for larger issues? Empirically, the evidence is mixed. Simon [65], [66], Duffie [18], Seligman [64] and Fleming [29] find that the larger issues lead to lower prices (higher yields), while Amihud and Mendelson [2], Kamara [51], Warga [69], and Elton and Green [23] find the opposite: The liquidity effect predominates, resulting in higher prices (lower yields) for larger issues. There might be a nonlinear relationship. Liquidity may increase prices up to a certain point, but then finite demand for any individual security reduces the attractiveness of additional supply.

\section{The Treasury Futures Market}

Spot markets are not the only markets for U.S. Treasuries. The Chicago Board of Trade (CBOT) has active futures markets for 2-, 5-, 10- and 30-year U.S. Treasuries. Table 1 briefly describes 
the CBOT contracts and pricing conventions.

[INSERT Table 1 HERE]

Like other exchange-traded derivatives, Treasury futures have two advantages: trading is highly liquid and marking-to-market minimizes counterparty risk. The CBOT open auction trading hours are 7:20 am to 2:00 pm, Central Time, Monday through Friday; the CBOT electronic market functions from 6:00 pm to 4:00 pm, Central Time, Sunday through Friday. All Treasury contracts have a March-June-September-December cycle.

A variety of Treasury instruments meet the criteria to be deliverable issues. Table 1 describes the pricing conventions and the characteristics of the assets that may be delivered to satisfy the contracts. The CBOT defines "conversion factors" that adjust the quoted futures prices for the asset that is actually delivered. Despite these conversion factors, one issue will be the "cheapest to deliver." Cash prices at delivery depend on both the conversion factor for a particular bond and the interest accrued on that bond since the last coupon payment.

Although agents frequently use the futures markets for hedging or taking positions on future price movements, only a modest amount of microstructure research has focused on futures markets. Brandt, Kavajecz, and Underwood [11] show that futures and spot market order flow are useful in predicting daily returns in each market and that the type of trader influences the effect of order flow. Mizrach and Neely [59] show that futures markets contribute a substantial amount of price discovery to U.S. Treasury markets. Campbell and Hendry [12] compare price discovery in the 10-year bond and futures contracts in both the United States and Canada.

\section{Seasonality and Announcement Effects}

Seasonality and announcement effects are intimately related to the microstructure literature in that the latter seeks to explain how markets with heterogeneous agents react to the release of information.

\subsection{Seasonality and macroeconomic announcements}

The earliest studies considered the issue of daily seasonality in Treasuries. Flannery and Protopapadakis [27] document differing day-of-the-week patterns in Treasuries and stock indices. The patterns in the prices of Treasuries securities vary by maturity and differ from those found in stock 
indices. They conclude that no single factor explains seasonal patterns across asset classes. In contrast to this day-of-the-week effect in spot T-bills, Johnston et al. [50] find day-of-the-week effects in government national mortgage association (GNMA) securities, T-note, and T-bond futures, but not in T-bill futures. The fact that day-of-the-week effects exist in spot T-bills but not in T-bill futures points up the importance of futures settlement rules.

Later studies began to consider the effects of macro announcements on price changes, volatility, volume and spreads. Macroeconomic announcements have been an especially popular subject of study because they occur at regular intervals that can be anticipated by market participants. The existence of survey expectations about upcoming macro announcements permits researchers to identify the "shock" component of the announcement, which allows them to investigate the differential effects of anticipated and unanticipated news releases of different magnitudes.

Ederington and Lee [20] [21] did the seminal modern work with intraday data on macro announcement effects in bond markets. They found that volatility increases before the announcement and remains elevated for some time afterwards. The employment, PPI, CPI and durable goods orders releases produce the greatest impact of the 9 significant announcements, out of 16 studied. Ederington and Lee [22] follow up on their earlier studies by linking the literatures on seasonality and announcements in the bond market. Comparing the contributions of past volatility, seasonality and announcements in predicting intraday volatility bond futures data and exchange rates, these authors argue that announcements account for much of the apparent seasonality in interest rate volatility.

One of the earliest important results was that bond market prices react more strongly to macro announcements than do equity markets. Fleming and Remolona [32] [34] examined the 25 largest price changes in the GovPX data and related them all to macroeconomic announcements. Fleming and Remolona [34] note: "In contrast to stock prices, U.S. Treasury security prices largely react to the arrival of public information on the economy." Fleming and Remolona [32] [33] attribute the relative sensitivity of bond markets to the fact that bond prices depend only on expected discount rates while stock prices are also determined by future expected dividends. Macro announcements can have little or no effect on stock prices if their effects on expected dividends and discount rates offset each other.

Several studies used more sophisticated econometric procedures to evaluate the impact of announcements on persistence in volatility in a full model. Jones, Lamont and Lumsdaine [49] exam- 
ine volatility patterns in the 5-year Treasury market around U.S. announcements. Daily volatility from an ARCH-M does not persist for days after announcements and the authors interpret this as indicating that agents rapidly incorporate announcement information into prices. Weekly volatility displays a U-shaped pattern; the largest price changes occur on Mondays and Fridays. Further, Jones, Lamont and Lumsdaine [49] find a risk premium in returns on days of announcements. Bollerslev, Cai, and Song [8] also consider the interaction of announcements and persistence in volatility with 5-minute U.S. Treasury bond data. Modeling the intraday volatility patterns and accounting for announcements reveals long-memory in bond market volatility.

An important issue in microstructure is the determination of bid-ask spreads. Balduzzi, Elton, and Green [4] use intraday GovPX data to look at the effects of macro announcements on volume, prices and spreads. Confirming previous findings, prices adjust to news within one minute while increases in volatility and volume persist for up to 60 minutes. Spreads initially widen but then return to normal after 5 to 15 minutes. News releases explain a substantial amount of bond market volatility. Importantly, Balduzzi, Elton, and Green [4] argue that the differential impact of news on long and short bond prices indicates that at least two factors will be needed for models of the yield curve. They also present evidence that discontinuities (jumps) will be important in modeling bond prices.

Some recent papers have relaxed the restrictive assumption that announcements influence Treasury market variables in a linear, symmetric fashion. For example, Christie-David, Chaudhry, and Lindley [15] allow the effects of announcement shocks to depend on the size and sign of the shock. They measure these nonlinear effects on the intraday 10- and 30-year Treasury futures from 1992 to 1996.

Most studies of the effects of volatility have measured such variation with some function of squared returns. One can use the volatility implied by options prices, however, to measure expected volatility over longer horizons. Heuson and $\mathrm{Su}$ [45], for example, show that implied volatilities from options on Treasuries rise prior to macro announcements and that volatilities quickly return to normal levels after announcements. Beber and Brandt [6] use intraday, tick data from 1995 to 1999 to determine that macro announcements reduce the variance of the option-implied distribution of U.S. Treasury bond prices. The content of the news and economic conditions explain these changes in higher-order moments. The study attributes the results to time-varying risk premia rather than relative mispricing or changing beliefs. 
In a comprehensive study of the impact of U.S. macroeconomic announcements across asset markets, Andersen, Bollerslev, Diebold and Vega [3] study the reaction of international equity, bond and foreign exchange markets. They confirm that U.S. macroeconomic news drives bond prices, as well as those of the other assets.

\subsection{Monetary policy announcements}

Researchers have carefully investigated the effects of the Federal Reserve's actions on the Treasury market. While the literature has examined the effect of a wide variety of monetary policy behavior and communications - e.g., open market operations, FOMC news releases, speeches, etc. - on many aspects of Treasury market behavior, a large subset of these papers deal with one specific topic: The effect of federal funds target changes on the Treasury yield curve.

\subsubsection{Federal funds target changes and the Treasury yield curve}

The "expectations hypothesis of the term structure" motivates research on how the short- and long-end of the Treasury yield curve react to unexpected changes in the federal funds target rate. That is, if the FOMC increases overnight interest rates, how does this change short- and long-term rates?

Using data on 75 changes in the federal funds target from September 1974 through September 1979, Cook and Hahn [16] find that these target changes caused larger movements in short-term rates than in intermediate- and long-term Treasury rates. A difficulty with interpreting the Cook and Hahn [16] results is that efficient markets presumably can often anticipate most or all of a target change and such expectations are already incorporated into the yield curve. To confront this problem, Kuttner [53] decomposes target changes into anticipated and unanticipated components, finding - unsurprisingly - that Treasury rates respond much more strongly to unanticipated changes and that the results are consistent with the expectations hypothesis of the term structure. That is, the anticipated component of an interest rate change does not affect expectations. Hamilton [41] carefully reexamines the work of Kuttner [53], showing that it is robust to uncertainty about the dates of target changes and the effect of learning by market participants.

Poole and Rasche [62] also decompose federal funds target changes into expected and unexpected components - but use a later contract month than Kuttner [53] to avoid problems associated with computation of the contract payoff. They find that interest rates across the maturity spectrum fail to respond to the anticipated components of the changes in the intended funds rate. 
Poole, Rasche and Thornton [63] consider how changes in FOMC procedures affect the impact of target changes on interest rates. This study first succinctly describes the changes in FOMC procedures in the 1990s. The FOMC began to contemporaneously announce policy actions in 1994 and adopted this as formal policy in 1995. Starting in August 1997, each policy directive has included the quantitative value of the "intended federal funds rate." And since 1999, the FOMC has issued a press release after each meeting with the value for the "intended federal funds rate" and, in most cases, an assessment of the balance of risks. After describing such procedural changes, Poole, Rasche and Thornton [63] go on to consider the response of the Treasury yield curve to funds rate target changes both before and after the FOMC began contemporaneously announcing target changes in 1994. In doing so, these authors account for measurement error in expectations and uncertainty about the dates of target changes and even whether market participants understood that the Federal Reserve was targeting the funds rate prior to 1994. They assess the market's knowledge of targeting by examining news reports. While short-rates respond similarly in both subperiods, long rates do not respond as strongly to funds rate target changes after 1994. The authors interpret their results as being consistent with the Fed's greater transparency about longrun policy in the second subsample. With long-run expectations more firmly anchored, unexpected changes in the funds target have smaller effects on long rates.

One puzzle that has emerged from this literature is that the average effect of changes in the federal funds target on the yield curve is modest, despite the facts that such changes should be an important determinant of the yield curve and that yields are highly volatile around FOMC announcements. Fleming and Piazzesi [31] claim to partially resolve this puzzle by illustrating that such yield changes depend on the shape of the yield curve.

This literature on the reaction of the Treasury market to monetary policy has become progressively more sophisticated in assessing market expectations of Fed policy and modeling institutional features of the futures market and Fed operations. Nevertheless, the underlying conclusion that unanticipated target changes lead to large price increases on short-term Treasuries and smaller changes on the prices of long-term Treasuries has been remarkably robust.

\subsubsection{Other Federal Reserve behavior and the Treasury market}

There has been a substantial literature analyzing how other types of Federal Reserve behavior have influenced the Treasury market. The literature has considered open market operations, FOMC statements, Congressional testimonies, and FOMC member speeches. 
Open market operations are similar to macroeconomic announcements in that they are potentially important bond market events, occurring at regularly scheduled times. Harvey and Huang [43] used intraday data from 1982 to 1988 to examine how Federal Reserve open market operations influenced foreign exchange and bond markets. The paper finds that Treasury market volatility increases during open market operations, irrespective of whether they add or drain reserves. Oddly, volatility increases even more during the usual time for open market operations if there are no such transactions. The authors interpret this finding as indicating that open market operations actually smooth volatility.

Early studies made the simplifying assumption that the effect of macro announcements on the Treasury market was constant over time. This is not necessarily the case, of course. For example, the effect of macro announcements on the Treasury market might depend on monetary policy priorities. Kearney [52] characterizes the changing response of daily 3-month Treasury futures to the employment report over 1977 to 1997 and relates it to the changing importance of employment in the Fed's reaction function.

de Goeij and Marquering [17] also considers how both macro announcements and monetary policy events affect the U.S. Treasury market. Using daily data from 1982 to 2004 de Goeij and Marquering [17] find that macro news announcements strongly affect the daily volatility of longerterm Treasury instruments while FOMC events affect the volatility of shorter-term instruments.

Some studies have explored more esoteric components of information about monetary policy. Boukus and Rosenberg [9], for example, use Latent Semantic Analysis to decompose the information content of FOMC minutes from 1987 to 2005. They then relate the information content to current and future economic conditions. Chirinko and Curran [13] argue that Federal Reserve speeches, testimonies, and meetings increase price and trading volatility on the 30-year bond market. FOMC meetings are the most important of the events considered. They go on to consider whether these Federal Reserve events merely create noise or transmit information about the future policy decisions or the state of the economy. They conclude that such events may reduce welfare by "overwhelming private information," creating herding behavior.

\subsection{Announcements and Liquidity Variation}

The literature on variation in liquidity and price effects overlaps with the literature on macroeconomic announcements. The seminal work of Amihud and Mendelson [2] showed that yields on short-time-to-maturity Treasuries vary inversely with liquidity. That is, more liquid assets 
have lower yields/higher prices. Harvey and Huang [43] discovered elevated volatility in interest rate (and foreign exchange) futures markets, in the first 60-70 minutes of trading on Thursdays and Fridays. Ederington and Lee [20] confirmed Harvey and Huang [43]'s speculation that major macroeconomic announcements - especially the employment report, the PPI, the CPI, and durable goods orders - create the intraday and intraweek patterns in the volatility of Treasury bond futures. Volatility is very high after announcements and remains elevated for hours. Fleming and Remolona [32] extend this work to show that the 25 greatest surges in activity in the 5-year on-the-run bond market came on macroeconomic announcement days, within 70 minutes of the announcement. The most important announcements for trading surges were employment reports, fed funds targets, 30year auctions, 10-year auctions, the CPI, NAPM surveys, GDP, retail sales, and 3-year auctions. Releases that affect prices also matter for trading activity. Fleming and Remolona [32] observe that timeliness, the degree of surprise in the announcement and market uncertainty also increase announcements' impact on trading.

Researchers continued to explore the impact of variation in liquidity caused by other events. For example, Fleming [28] exploits exogenous variation in Treasury issuance to show that securities that are "reopened" - the Treasury sells additional quantities of existing securities - have greater liquidity, lower spreads, than comparable assets. Paradoxically, this higher liquidity does not produce lower yields for the reopened securities.

More recent papers have explored variation in liquidity and volatility across markets. Chordia, Sarkar and Subrahmanyam [14] estimate a vector autoregression (VAR) in liquidity and volatility variables in stock and bond markets. They find that common factors make the variables' innovations highly correlated. Volatility shocks predict liquidity variables.

\subsection{End-of-the-year patterns in one-month Treasury Bills}

The previous sets of papers studied daily and intraday seasonality, often as caused by macroeconomic or Federal Reserve announcements. Short-term Treasury bills also exhibit year-end seasonality, however. Market participants consider Treasury market instruments of 30 days or less to be highly liquid, close - but not perfect - substitutes for cash. The fact that short-term Treasuries are not perfect substitutes for cash is presumably what allows the New York Desk to use open market operations to manipulate short-term interest rates through a liquidity effect. A peculiar year-end pattern in one-month Treasury yields reinforces this evidence that such Treasuries are not perfect substitutes for cash. 
Following on related work of Griffiths and Winters [40] in repos, Griffiths and Winters [39] find that yields on one month T-Bills (and other one-month securities) increase significantly at the beginning of December, remain high during December, and return to normal a few days before the year-end. This pattern does not exist in three-month T-bills. Neely and Winters [60] find similar patterns in the one-month LIBOR futures market.

Griffiths and Winters [38] [39] [40] explain this December effect by asserting that a year-end preference for liquidity drives the year-end surge in short-term interest rates. Debt holder (lenders in the money markets) start to liquidate their one-month securities in the last few days of November to meet cash obligations at the end-of-December. This preference for liquidity drives up one-month interest rates for most of December. Liquidity demand returns to normal at the end of December as investors repurchase short-term instruments, and interest rates return to normal levels.

\section{Discontinuities in the U.S. Treasury Market}

The literature on discontinuities (or jumps) in Treasury prices is closely related to the literature on announcements, as announcements are obvious candidates to explain jumps. Three recent papers have looked at discontinuities in U.S. Treasury prices. Huang [47] estimates daily jumps with bi-power variation on 10 years of 5-minute data on S\&P 500 and U.S. T-bond futures to measure the response of volatility and jumps to macro news. He identifies a major role for payroll news in bond market jumps by analyzing their conditional distributions and regressing continuous and jump components on measures of disagreement and uncertainty concerning future macroeconomic states. Huang [47] also finds that the bond market is relatively more responsive than the equity market.

Dungey, McKenzie, and Smith [19] estimate jumps and cojumps (simultaneous discontinuities in multiple markets) in the term structure of U.S. Treasury rates. They find that the middle of the yield curve often cojumps with one of the ends, while the ends of the curve exhibit a greater tendency for idiosyncratic jumps. Macro news is strongly associated with cojumps in the term structure. Using BrokerTec data from 2003-2005, Jiang, Lo, and Verdelhan [48] extend this work by focusing on the role of liquidity shocks - estimated from the limit order book-in jumps and the relation of jumps to order flow and price discovery.

Lahaye, Laurent and Neely [54] examine jumps and cojumps across foreign exchange, stock, gold and 30-year Treasury futures. Discontinuities in bond futures prices were larger but less 
frequent than those in foreign exchange rates and smaller and about as frequent as those in equity markets. News announcements appear to cause many cojumps of bond prices with prices of other types of assets.

\section{Order Flow in the U.S. Treasury Market}

The effect of order flow on prices has been a popular recent topic in microstructure. Several papers have explored the impact of order flow on prices and the ways in which macro/monetary announcements influence these impacts.

Huang, Cai, and Wang [46] use intraday 1998 GovPX spot data on the 5-year Treasury note to characterize trading patterns of primary dealers, announcement effects and volatility-volume relations. The paper finds that both public information (i.e., announcements) and dealer inventory/order flow affect trading frequency.

Green [37] uses the Madhavan, Richardson, and Roomans [55] model to study the impact of GovPX trading in 5-year around announcements. Order flow has its largest price impact after larger macro surprises, times of greater uncertainty about the announcement, and times of high liquidity. Green [37] concludes that order flow does reveal information about riskless rates.

Brandt and Kavajecz [10] find that order flow imbalances can explain up to $26 \%$ of the dayto-day variation in yields on non-announcement days. In contrast to Green [37], they find that order flow has its strongest impact at times of low liquidity. Brandt, Kavacejz, and Underwood [11] extend the work of Brandt and Kavajecz [10] to control for trader type and macroeconomic announcements in explaining the impact of bond market order flow on futures prices.

Menkveld, Sarkar, and Van der Wel [56] confirm earlier conclusions that announcements have significant effects on 30-year Treasury yields and they also find that customer order flow is much more informative on announcement days than on non-announcement days. They go on to investigate the profits that different types of traders make on announcement and non-announcement days.

At high frequencies, order flow is highly autocorrelated. A dynamic analysis of the market resilience requires modeling this formally. We turn to empirical modeling of the Treasury market order book in the next section. 


\section{Modeling The Limit Order Book}

A purchase or a sale of a Treasury bond influences prices directly as trades work their way up the supply or demand curves. We would like to know whether these effects are large and long-lasting. To address this question, we must introduce a dynamic model of the limit order book.

Hasbrouck [44] proposed to study intra-day price formation with a standard bivariate vector autoregressive (VAR) model. Time $t$ here is measured in 1-minute intervals. Let $r_{t}$ be the percentage change in the transaction price and $x_{t}^{0}$ be the sum of signed trade indicators $(+1$ for buyer initiated, -1 for seller initiated) over minute $t$. Treasury market data sets typically indicate trade initiation as a "hit" -1 or a "take" +1 .

The bivariate vector autoregression assumes that causality flows from trade initiation to returns by permitting $r_{t}$ to depend on the contemporaneous value for $x_{t}^{0}$, but not allowing $x_{t}^{0}$ to depend on contemporaneous $r_{t}$. The model for returns is specified as follows

$$
\left[\begin{array}{c}
r_{t} \\
x_{t}^{0}
\end{array}\right]=\sum_{i=1}^{5}\left[\begin{array}{c}
a_{r, i} \\
a_{x, i}
\end{array}\right] r_{t-i}+\left[\begin{array}{c}
\sum_{i=0}^{15} b_{r, i} \\
\sum_{i=1}^{15} b_{x, i}
\end{array}\right] x_{t-i}^{0}+\left[\begin{array}{c}
u_{r, t} \\
u_{x, t}
\end{array}\right]
$$

Mizrach and Neely [58] use 5 lags of the return series and 15 lags of the signed trades. The market impact is then defined as the dynamic effect of a buy shock to the return series,

$$
\frac{\partial r_{t+n}}{\partial x_{t}}
$$

Mizrach and Neely [58] provide 15 minute market impact estimates from the GovPX market in 1999. The 2-year note is most resilient with prices only $0.0042 \%$ higher following a buyer initiated trade. The 30-year bond is the least liquid, with prices rising $0.0229 \%$ following a buy order. Mizrach and Neely also report 2004 estimates for the Cantor electronic limit order book. Market impacts range from 45 to $88 \%$ lower in the more liquid eSpeed ECN market. Fleming and Mizrach [30] find further reductions in market impacts on the BrokerTec ECN for 2005 and 2006.

\section{Price Discovery}

A crucial issue in the market microstructure literature is price discovery. This is the process by which prices embed new information. In the Treasury market, price discovery occurs in both the secondary spot market and in the futures markets at the Chicago Board of Trade (CBOT). The degree to which each market contributes to price discovery is a natural issue to address.

To investigate relative price discovery in these two Treasury markets, Mizrach and Neely [59] 
follow Hasbrouck [44] and assume that the price series have a unit root, are cointegrated, and have an $r^{\text {th }}$ order VAR representation,

$$
p_{t}=\Phi_{1} p_{t-1}+\Phi_{2} p_{t-2}+\cdots+\Phi_{r} p_{t-r}+u_{t}
$$

It follows that the $N$ returns,

$$
r_{t}=\left[\begin{array}{c}
p_{1, t}-p_{1, t-1} \\
\vdots \\
p_{N, t}-p_{N, t-1}
\end{array}\right]=\Delta p_{t}
$$

have the convenient Engle-Granger [24] error-correction representation,

$$
\Delta p_{t}=\alpha z_{t-1}+A_{1} \Delta p_{t-1}+\cdots+A_{r} \Delta p_{t-r-1}+u_{t},
$$

where $z_{t}$ is an error-correction term of rank $N-1$.

We analyze price discovery using the moving average representation of our return process (3),

$$
\Delta p_{t}=\Theta(L) \varepsilon_{t}
$$

The disturbances are mean zero and serially uncorrelated, $E\left[\varepsilon_{i, t}\right]=0$ and $\operatorname{cov}\left[\varepsilon_{i, t}, \varepsilon_{i, t-r}\right]=0$, but they may be contemporaneously correlated, $\operatorname{cov}\left[\varepsilon_{i, t}, \varepsilon_{j, t}\right] \neq 0$.

The information share is related to the long run impulse responses, $\Theta(1)=\sum_{j=0}^{\infty} \Theta\left(L^{j}\right)$, the permanent effect of the shock vector on the Treasury prices. Cointegration makes the long run multipliers common across all markets,

$$
\Theta(1)=\left[\begin{array}{ccc}
\theta_{1} & \cdots & \theta_{N} \\
\vdots & & \vdots \\
\theta_{1} & \cdots & \theta_{N}
\end{array}\right]
$$

To eliminate contemporaneous correlation among the error terms in (5), we decompose $\Omega=$ $E\left[\varepsilon_{t} \varepsilon_{t}^{\prime}\right]$, the $N \times N$ covariance matrix, to find a lower triangular matrix $M$, whose $i, j^{t h}$ element we denote $m_{i j}$, such that $M M^{\prime}=\Omega$. The Hasbrouck [44] information share for market $j$ is defined as

$$
H_{j}=\frac{\left[\sum_{i=j}^{n} \theta_{i} m_{i j}\right]^{2}}{\left[\sum_{i=1}^{n} \theta_{i} m_{i 1}\right]^{2}+\left[\sum_{i=2}^{n} \theta_{i} m_{i 2}\right]^{2}+\cdots+\left(\theta_{n} m_{n n}\right)^{2}},
$$

where the $\theta_{i}$ s are the elements of row $i$ of the long-run multipliers in (6). Because the Choleski decomposition is not unique, the information share will vary with the order of the equations in the VAR.

Mizrach and Neely [59] pair spot and maturity matched futures for the 2-year, 5-year and 10-year on-the-run spot notes. This calculation requires us to adjust futures prices according to the on-the-run spot instruments with which we compare them. The CBOT provides adjustment 
factors for each instrument. These adjustments typically make a single bond the cheapest to deliver (CTD), but the CTD is typically off-the-run. Nevertheless, the CTD off-the-run bonds and the most liquid on-the-run bonds are very close substitutes - their daily returns are highly correlatedso it is reasonable to examine price discovery between futures prices and on-the-run bonds, despite the fact that they are not identical.

Mizrach and Neely [59] find that information shares rise with the growth of the GovPX market, but fall as the ECNs take market share from GovPX voice markets. The spot market share is highest for the 2-year note, reaching $86 \%$, while the 10 -year spot market share never exceeds $50 \%$. In addition, relative market liquidity measures like spreads, trades and volatility each strongly explain daily relative price discovery shares. Mizrach and Neely [59] compute both upper and lower bound estimates of the information shares. They also report estimates based on the Harris, McInish and Wood [42] methodology.

Campbell and Hendry [12] find similar results for the Canadian government bond market. They find that the information share in the 10-year spot note is below $50 \%$ in nearly all their sample of several months between 2002 and 2004. Upper and Werner [67] find that price discovery in the German Bund is dominated by the futures market, and in times of stress, like the 1998 Long Term Capital Management Crisis, the spot market information share falls to essentially zero. Upper and Werner [67], however, compare the futures market to the relatively illiquid, CTD bonds. This might explain their finding that the spot market does very little price discovery.

\section{Future Directions}

This article has reviewed the microstructure of the U.S. Treasury market. The Open Market Desk at the Federal Reserve Bank of New York plays a uniquely important role in the Treasury market by using transactions in those securities to adjust the level of bank reserves. Primary dealers are key players in both Treasury auctions and the Fed's open market operations. The Treasury market consists of several phases: when-issued, primary, on-the-run and off-the-run. Two ECNs, eSpeed and BrokerTec, intermediate the most active trading, during the on-the-run phase. The Treasury futures market at the CBOT complements trading in the spot market.

Treasury markets exhibit end-of-year, daily and intraday seasonality. Macro and Federal Reserve announcements are responsible for a substantial part of the daily and intraday seasonality. The literature studying the impact of order flows on Treasury prices has also considered how macro 
news and Federal Reserve actions influence such impact.

The futures markets in Chicago play an important role in price discovery, and a discussion of Treasury microstructure needs to take this into account. Both spot and futures markets are quite resilient and recent research on the Treasury ECNs suggest that the market continues to become more liquid. Fleming and Mizrach [30] report that volume has increased almost 5 times since 2001. This increase in trading volume accompanies a decline in the importance of the primary dealers. Beales and Titt reported in the Financial Times in March 2007 that hedge funds now account for $80 \%$ of trading activity in the Treasury market with only a $20 \%$ share for the primary dealers. One large fund alone, Citadel, accounts for $10 \%$ of the trading volume on eSpeed and BrokerTec. It was perhaps inevitable that trading by the millisecond would come to the Treasury market as it did to equities and foreign exchange. Perhaps we should only be surprised that it took so long.

The Treasury market plays a central role in the credit market. Times of financial crisis highlight the Treasury market's role as a safe haven for investors both in the U.S. and overseas. Treasury securities also serve as benchmarks for complex derivatives like mortgage backed securities and structured loans like collateralized debt obligations. The microstructure of the U.S. Treasury market is fundamental to our understanding of the global financial markets. 


\section{References}

[1] Akhtar, M.A. (1997). "Understanding Open Market Operations." Public Information Department, Federal Reserve Bank of New York, http://research.stlouisfed.org/aggreg/meeks.pdf

[2] Amihud, Y. and H. Mendelson (1991). "Liquidity, Maturity, and the Yields on U.S. Treasury Securities," Journal of Finance 46, 1411-25.

[3] Andersen, T. G., T. Bollerslev, F. X. Diebold, and C. Vega (2007). "Real-Time Price Discovery in Stock, Bond and Foreign Exchange Markets," Journal of International Economics, 73, 251-77.

[4] Balduzzi, P., E. J. Elton, and T.C. Green (2001). "Economic News and Bond Prices: Evidence From the U.S. Treasury Market." Journal of Financial and Quantitative Analysis 36, 523-43.

[5] Barclay, M. J., T. Hendershott, and K. Kotz (2006). "Automation Versus Intermediation: Evidence from Treasuries Going Off the Run," Journal of Finance 61, 2395-2414.

[6] Beber, A. and M.W. Brandt (2006). "The Effect of Macroeconomic News on Beliefs and Preferences: Evidence from the Options Market." Journal of Monetary Economics 53, 1997-2039.

[7] Bernanke, B. S. (2005). "Implementing Monetary Policy," Remarks at the Redefining Investment Strategy Education Symposium, Dayton, Ohio.

[8] Bollerslev, T., J. Cai and F.M. Song (2000). "Intraday Periodicity, Long Memory Volatility, and Macroeconomic Announcement Effects in the US Treasury Bond Market." Journal of Empirical Finance 7, 37-55.

[9] Boukus, E. and J.V. Rosenberg (2006). "The Information Content of FOMC Minutes." Working paper, Federal Reserve Bank of New York.

[10] Brandt, M.W. and K. A. Kavajecz (2004). "Price Discovery in the U.S. Treasury Market: The Impact of Orderflow and Liquidity on the Yield Curve," Journal of Finance 59, 2623-2654.

[11] Brandt, M.W., K. A. Kavajecz, and S. E. Underwood (2007). "Price Discovery in the Treasury Futures Market," Journal of Futures Markets 27, 1021-51.

[12] Campbell, B. and S. Hendry (2007). "Price Discovery in Canadian and U.S. 10-Year Government Bond Markets," Working Paper 07-43, Bank of Canada.

[13] Chirinko, R. S. and C. Curran (2006). "Greenspan Shrugs: Formal Pronouncements, Bond Market Volatility, And Central Bank Communication." Presented at The American Economic Association Meetings.

[14] Chordia, T., A. Sarkar, and A. Subrahmanyam (2005). "An Empirical Analysis of Stock and Bond Market Liquidity," Review of Financial Studies 18, 85-129. 
[15] Christie-David, R.; M. Chaudhry and J.T. Lindley (2003). "The Effects of Unanticipated Macroeconomic News on Debt Markets." Journal of Financial Research 26, 319-39.

[16] Cook, T., and T. Hahn (1989). "The Effect of Changes in the Federal Funds Rate Target on Market Interest Rates in the 1970s," Journal of Monetary Economics 24, 331-351.

[17] de Goeij, P. and W. Marquering (2006). "Macroeconomic Announcements and Asymmetric Volatility in Bond Returns," Journal of Banking and Finance 30, 2659-80.

[18] Duffie, D. (1996). "Special Repo Rates," Journal of Finance 51, 493-526.

[19] Dungey, M., M. McKenzie, and V. Smith (2007) "News, No-News and Jumps in the U.S. Treasury Market," unpublished manuscript, Cambridge University.

[20] Ederington, L. H. and J.H. Lee (1993). "How Markets Process Information: News Releases and Volatility." Journal of Finance 48, 1161-91.

[21] Ederington, L.H. and J. H. Lee (1995). "The Short-Run Dynamics of the Price Adjustment to New Information." Journal of Financial and Quantitative Analysis 30, 117-34.

[22] Ederington, L.H. and J. H. Lee (2001). "Intraday Volatility in Interest-Rate and Foreign-Exchange Markets: ARCH, Announcement, and Seasonality Effects," Journal of Futures Markets 21, 517-52.

[23] Elton, E.J. and T. C. Green (1998). "Tax and Liquidity Effects in Pricing Government Bonds," Journal of Finance 53, 1533-1562.

[24] Engle, R., and C. Granger (1987). "Co-integration and Error Correction Representation, Estimation and Testing," Econometrica 55, 251-76

[25] Fabozzi, F. J. and M. J. Fleming (2005). "U.S. Treasury and Agency Securities," The Handbook of Fixed Income Securities, 7th ed., New York: McGraw Hill.

[26] Federal Reserve Bank of New York, Markets Group (2007). "Domestic Open Market Operations During 2006." Federal Reserve Bank of New York, http://www.ny.frb.org/markets/omo/omo2006.pdf

[27] Flannery, M., and A. Protopapadakis (1988). "From T-Bills to Common Stocks: Investigating the Generality of Intra-Week Return Seasonalities." Journal of Finance 43, 431-450.

[28] Fleming, M. (2002). "Are Larger Treasury Issues More Liquid? Evidence from Bill Reopenings," Journal of Money, Credit, and Banking 34, 707-35.

[29] Fleming, M.(2003). "Measuring Treasury Market Liquidity," Federal Reserve Bank of New York Economic Policy Review 9, 83-108.

[30] Fleming, M. and B. Mizrach (2008). "The Microstructure of a U.S. Treasury ECN: The BrokerTec Platform," http://ssrn.com/abstract $=1117975$. 
[31] Fleming, M. and M. Piazzesi (2005). "Monetary Policy Tick-by-Tick." Working paper, Federal Reserve Bank of New York.

[32] Fleming, M. and E. M. Remolona (1997). "What Moves The Bond Market?" Federal Reserve Bank of New York Economic Policy Review 3, 31-50.

[33] Fleming, M, and E. M. Remolona (1999a). "Price Formation and Liquidity in the US Treasury Market: The Response to Public Information," Journal of Finance 54,1901-15.

[34] Fleming, M.and E. M. Remolona (1999b). "What Moves Bond Prices?" Journal of Portfolio Management 25, 28-38.

[35] Garbade, K. D. and J. F. Ingber (2005). "The Treasury Auction Process: Objectives, Structure, and Recent Adaptations," Federal Reserve Bank of New York Current Issues in Economics and Finance 11, 1-11.

[36] Goldreich, D., B. Hanke, and P. Nath (2005). "The Price of Future Liquidity: Time-Varying Liquidity in the U.S. Treasury Market," Review of Finance, 9, 1-32.

[37] Green, T.C. (2004). "Economic News and the Impact of Trading on Bond Prices," Journal of Finance 59, 1201-1233.

[38] Griffiths, M., and D. Winters (1997). "On a Preferred Habitat for Liquidity at the Turn-of-the-Year: Evidence from the Term-Repo Market." Journal of Financial Services Research 12, 21-38.

[39] Griffiths, M., and D. Winters (2005a). "The Turn-of-the-Year in Money Markets: Tests of RiskShifting Window Dressing and Preferred Habitat Hypotheses," Journal of Business 78, 1337-1364.

[40] Griffiths, M., and D. Winters (2005b). "The Year-End Price of Risk in a Market for Liquidity," Journal of Investment Management 3, 99-109.

[41] Hamilton, J. D. (2007) . "Assessing Monetary Policy Effects Using Daily Fed Funds Futures Contracts," forthcoming in the Federal Reserve Bank of St. Louis Review.

[42] Harris, F., T. McInish, and R. Wood (2002). "Security Price Adjustment Across Exchanges: An Investigation of Common Factor Components for Dow Stocks," Journal of Financial Markets 5, 277-308.

[43] Harvey, C.R. and R. D. Huang (2002). "The Impact of the Federal Reserve Bank's Open Market Operations." Journal of Financial Markets 5, 223-57.

[44] Hasbrouck, J. (1991). "Measuring the Information Content of Stock Trades," Journal of Finance 46, 179-207.

[45] Heuson, A. J. and T. Su (2003). "Intra-day Behavior of Treasury Sector Index Option Implied Volatilities around Macroeconomic Announcements," The Financial Review 38, 161-77. 
[46] Huang, R. D., J. Cai, and X.Wang (2002). "Information-Based Trading in the Treasury Note Interdealer Broker Market." Journal of Financial Intermediation 11, 269-296.

[47] Huang, X. (2006) "Macroeconomic News Announcements, Financial Market Volatility and Jumps," Unpublished manuscript, Duke University.

[48] Jiang, G. J., I. Lo, and A. Verdelhan, (2007). "Why Do Bond Prices Jump? A Study of the U.S. Treasury Market," unpublished manuscript, Eller College of Management, University of Arizona.

[49] Jones, C. M, O. Lamont and R.L. Lumsdaine. (1998). "Macroeconomic News and Bond Market Volatility." Journal of Financial Economics 47, 315-37.

[50] Johnston, E., W. Kracaw, and J. McConnell (1991). "Day-of-the-Week Effects in Financial Futures: An Analysis of GNMA, T-Bond, T-Note, and T-Bill contracts," Journal of Financial and Quantitative Analysis 26, 23-44.

[51] Kamara, A. (1994). "Liquidity, Taxes, and Short-Term Treasury Yields," Journal of Financial and Quantitative Analysis 29, 403-17.

[52] Kearney, A. A. (2004). "The Changing Impact of Employment Announcements on Interest Rates." Journal of Economics and Business 54, 415-429.

[53] Kuttner, K. N. (2001). "Monetary Policy Surprises and Interest Rates: Evidence from the Fed Funds Futures Market." Journal of Monetary Economics 47, 523-544.

[54] Lahaye, J., S.Laurent and C. J. Neely (2007). "Jumps, Cojumps and Macro Announcements," Federal Reserve Bank of St. Louis Working Paper 2007-032A.

[55] Madhavan, A., M. Richardson, and M. Roomans (1997). "Why do Securities Prices Change? A Transaction-Level Analysis of NYSE Stocks," Review of Financial Studies 10, 1035-1064.

[56] Menkveld, A.J., A. Sarkar and M. Van der Wel (2006). "The Informativeness of Customer Order Flow Following Macroeconomic Announcements: Evidence from Treasury Futures Markets." Unpublished manuscript.

[57] Meulendyke, A.M. (1998). "U.S. Monetary Policy \& Financial Markets." Federal Reserve Bank of New York, http://research.stlouisfed.org/aggreg/meulendyke.pdf

[58] Mizrach, B. and C. J. Neely (2006). "The Transition To Electronic Communication Networks in the Secondary Treasury Market," Federal Reserve Bank of St. Louis Review, 88, 527-41.

[59] Mizrach, B. and C. J. Neely (2007). "Information Shares in the U.S. Treasury Market," Journal of Banking and Finance, forthcoming.

[60] Neely, C. J.; and D. B. Winters (2006). "Year-End Seasonality in One-Month LIBOR Derivatives," Journal of Derivatives 13, 47-65 
[61] Nyborg, K.G. and S. Sundaresan (1986). "Discriminatory versus Uniform Treasury Auctions: Evidence from When-Issued Transactions," Journal of Financial Economics 42, 63-104.

[62] Poole, W. and R. H. Rasche (2000). "Perfecting the Market's Knowledge of Monetary Policy," Journal of Financial Services Research 18, 255-298.

[63] Poole, W., R. H. Rasche, and D. L. Thornton (2002). "Market Anticipations of Monetary Policy Actions." Federal Reserve Bank of St. Louis Review 84, 65-94.

[64] Seligman, J. (2001). "Is Last Money Dearest? An Analysis of U.S. Treasury Short Term Finance," Working paper, University of California, Berkeley.

[65] Simon, D.P. (1991). "Segmentation in the Treasury Bill Market: Evidence from Cash Management Bills," Journal of Financial and Quantitative Analysis 26, 97-108.

[66] Simon, D.P. (1994). "Further Evidence on Segmentation in the Treasury Bill Market," Journal of Banking and Finance 18, 139-51.

[67] Upper, C., and T. Werner (2002). "Tail Wags Dog? Time-Varying Information Shares in the Bund Market," Bundesbank Working Paper 24/02, Frankfurt, Germany.

[68] Vayanos, D. and P. Weill (2007). "A Search-Based Theory of the On-the-Run Phenomenon," Journal of Finance, forthcoming.

[69] Warga, A. (1992). "Bond Returns, Liquidity, and Missing Data," Journal of Financial and Quantitative Analysis 27, 605-17. 
Table 1

Contract Details from the CBOT Treasury Market

\begin{tabular}{|c|c|c|c|}
\hline Contract & Quote convention & Pricing example & Deliverable asset characteristics \\
\hline 2-year & $\begin{array}{l}1 / 32 \\
\& \text { quarters of } 32 \mathrm{nds}\end{array}$ & $\begin{array}{l}95-060=95+6 / 32 \\
95-062=95+6.25 / 32 \\
95-065=95+6.5 / 32 \\
95-067=95+6.75 / 32\end{array}$ & $\begin{array}{l}\text { U.S. Treasury notes with a face value } \geq \$ 200,000 \text { and } \\
\text { original maturity } \leq 5 \text { years and } 3 \text { months and } \\
\text { remaining maturity } \geq 1 \text { year and } 9 \text { months from the first day of the delivery month and } \\
\text { and remaining maturity } \leq \text { than } 2 \text { years from the last day of the delivery month. }\end{array}$ \\
\hline 5-year & $\begin{array}{l}1 / 32 \\
\text { and halves of } 32 \mathrm{nds}\end{array}$ & $\begin{array}{l}90-170=90+17 / 32 \\
90-175=90+17.5 / 32\end{array}$ & $\begin{array}{l}\text { U.S. Treasury notes with a face value } \geq \$ 100,000 \text { and } \\
\text { original maturity } \leq 5 \text { years and } 3 \text { months and } \\
\text { remaining maturity } \geq 4 \text { year and } 2 \text { months from the first day of the delivery month }\end{array}$ \\
\hline 10-year & $\begin{array}{l}1 / 32 \\
\text { and halves of } 32 \mathrm{nds}\end{array}$ & $\begin{array}{l}90-170=90+17 / 32 \\
90-175=90+17.5 / 32\end{array}$ & $\begin{array}{l}\text { U.S. Treasury notes with a face value } \geq \$ 100,000 \text { and } \\
\text { remaining maturity } \leq 10 \text { years } \\
\text { remaining maturity } \geq 6 \text { year and } 6 \text { months from the first day of the delivery month }\end{array}$ \\
\hline 30-year & $1 / 32 \mathrm{nds}$ & $85-12=85+12 / 32$ & $\begin{array}{l}\text { U.S. Treasury bonds with a face value } \geq \$ 100,000 \text { and } \\
\text { if callable: Not callable for at least } 15 \text { years from the first day of the delivery month; } \\
\text { if not callable: Remaining maturity } \geq 15 \text { years from the first day of the delivery month. }\end{array}$ \\
\hline
\end{tabular}

